$11-18-2013$

\title{
Cyclometalated Iridium(III) Complexes with Deoxyribose Substituents
}

\author{
Ayan Maity \\ Case Western Reserve University \\ Jung-Suk Choi \\ Cleveland State University, J.CHOI43@csuohio.edu \\ Thomas S. Teets \\ Massachusetts Institute of Technology \\ Nihal Deligonul \\ Case Western Reserve University
}

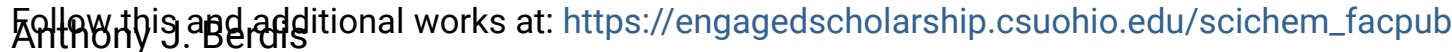

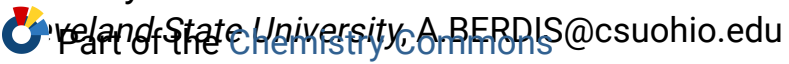

How does access to this work benefit you? Let us know!

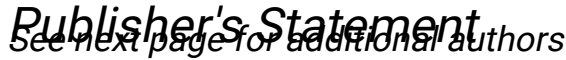

This is the accepted version of the following article: Maity, A.; Choi, J.; Teets, T. S.; Deligonul, N.; Berdis, A. J.; Gray, T. G. Cyclometalated Iridium(III) Complexes with Deoxyribose Substituents. Chemistry - A European Journal 2013, 19, 15924-15932., which has been published in final form at http://onlinelibrary.wiley.com/doi/10.1002/chem.201301776/full

\section{Recommended Citation}

Maity, Ayan; Choi, Jung-Suk; Teets, Thomas S.; Deligonul, Nihal; Berdis, Anthony J.; and Gray, Thomas G., "Cyclometalated Iridium(III) Complexes with Deoxyribose Substituents" (2013). Chemistry Faculty Publications. 173.

https://engagedscholarship.csuohio.edu/scichem_facpub/173

This Article is brought to you for free and open access by the Chemistry Department at EngagedScholarship@CSU. It has been accepted for inclusion in Chemistry Faculty Publications by an authorized administrator of EngagedScholarship@CSU. For more information, please contact library.es@csuohio.edu. 


\section{Authors}

Ayan Maity, Jung-Suk Choi, Thomas S. Teets, Nihal Deligonul, Anthony J. Berdis, and Thomas G. Gray 


\title{
Cyclometalated Iridium(III) Complexes with Deoxyribose Substituents
}

\author{
Ayan Maity, Jung-Suk Choi, Thomas S. Teets, Nihal Deligonul, \\ Anthony J. Berdis, and Thomas G. Gray
}

\begin{abstract}
Fundamental study of enzy matic nucleoside transport suffers for lack of optical probes that can be tracked noninvasively. Nucleoside transporters are integral membrane glycoproteins that mediate the salvage of nucleosides and their passage across cell membranes. The substrate recogni tion site is the deoxyribose sugar, often with little distinction among nucleobas
\end{abstract}

es. Reported here are nucleoside ana logues in which emissive, cyclometalat ed iridium(III) complexes are "clicked" to $\mathrm{C} 1$ of deoxyribose in place of can onical nucleobases. The resulting com

Keywords: click chemistry - fluo rescent probes - iridium - metala tion $\cdot$ nucleobases

\begin{abstract}
plexes show visible luminescence at room temperature and $77 \mathrm{~K}$ with $\mathrm{mi}$ crosecond length triplet lifetimes. A representative complex is crystallo graphically characterized. Transport and luminescence are demonstrated in cultured human carcinoma (KB3 1) cells.
\end{abstract}

\section{Introduction}

Iridium(III) has gained prominence in cell biology for lumi nescence tagging. Cyclometalated complexes of iridium(III) are rugged, coordinatively saturated organometallics that withstand the inhospitable settings of living cells. ${ }^{[111]}$ These complexes are high yielding phosphorescence lumophores that emit visible light across a range of wavelengths. Triplet luminescence arises from either a metal to ligand charge transfer (MLCT) state or a ligand centered excited state. $\left.^{[12} 21\right]$ Emission wavelengths are subject to rational tuning. ${ }^{[22}$ 27] The complexes' excited state properties make them light emitting beacons; their ground state attributes suggest them for experiments in cells. ${ }^{\text {[28 34] }}$

Cyclometalated iridium(III) complexes accommodate the standard techniques of bioconjugation. Reports of their at tachment to biologically relevant molecules are legion. ${ }^{[35]}$ Complexes have been tethered to biotin for binding and crosslinking streptavidin. ${ }^{[36,37]}$ Iridium(III) complexes have also been attached to steroids, such as estradiol. ${ }^{[38]}$ Lo and co workers report that emission of two distinct iridium com plexes tethered to estradiol intensifies upon binding to the receptor $E R \alpha^{[39]}$ Sugars have been conjugated to iridium complexes indirectly through tethers that end in amino oxy moieties. ${ }^{[40]}$ These functional groups undergo bioconjugation reactions with the carbonyl groups of reducing sugars. The resulting complexes enter HeLa cells, and perinuclear stain ing occurs. Internalization is rapid for the glucose conjugate and less so for those of galactose, lactose, or maltose.

Nucleoside transporters are integral membrane glycopro teins. ${ }^{[1]}$ These proteins regulate cellular proliferation, neuro transmission, and cardiovascular activity by mediating the passage of natural and synthetic nucleosides both in and out of mammalian cells. They are imperfectly understood, de spite being essential to cell survival and proliferation. In cells actively dividing, de novo nucleoside synthesis predom inates. In other cells, nucleosides are recycled, and nucleo side transporters enable salvaging. There are two broad classes of transporters: equilibrative nucleoside transporters (ENT) and concentrative nucleoside transporters (CNT). The equilibrative transporters move nucleosides into or out of the cell, along a concentration gradient. Concentrative nucleoside transporters ferry nucleosides inwards, against the gradient. For most CNTs, nucleoside transport is cou pled to $\mathrm{Na}^{+}$transport, and these proteins are sodium nu cleoside symporters. Another isoform, designated CNT3, utilizes $\mathrm{Na}^{+}$and/or $\mathrm{H}^{+}$to facilitate nucleoside transport. ${ }^{[42]}$

Many chemotherapeutic drugs are nucleoside ana logues, ${ }^{[43}$ 51] and their effectiveness depends on nucleoside transporters for cellular uptake. Mechanistic understanding of these glycoproteins is sparse, mainly because of limited structural information on such dynamic biomolecules. To date, there is a single report of a crystal structure of a CNT from the bacterium Vibrio cholera. ${ }^{[52]}$ Although more struc tures are likely to emerge, there is a clear need for probes that accurately report on the activity of transporters in cells and live animals. 
This work reports optical markers for the facilitated diffu sion of nucleosides. Nucleoside transporters recognize the sugar moiety; the nucleobase is secondary. We describe iridium(III) based emitters bound covalently to deoxyribose sugars through $\beta$ glycoside linkages. These non natural nu cleosides assemble in copper catalyzed $[3+2]$ cycloaddition reactions of azides with terminal alkyne precursors. Metala tion follows in thermal reactions with iridium(III) dimers. ${ }^{[53]}$ Instead of a nucleobase, the deoxyribose sugar supports cy clometalated iridium(III) at the $1^{\prime}$ position. The new probes are visible light emitters. Their syntheses and optical proper ties are disclosed, along with crystallographic findings, cellu lar experiments, and density functional theory calculations of a representative complex.

\section{Results and Discussion}

Synthesis: Synthesis of a chelating deoxyribose ligand pro ceeded as in Scheme 1. Concentrated hydrochloric acid (1.5 equiv) was treated with 2 deoxy D ribose in methanol.
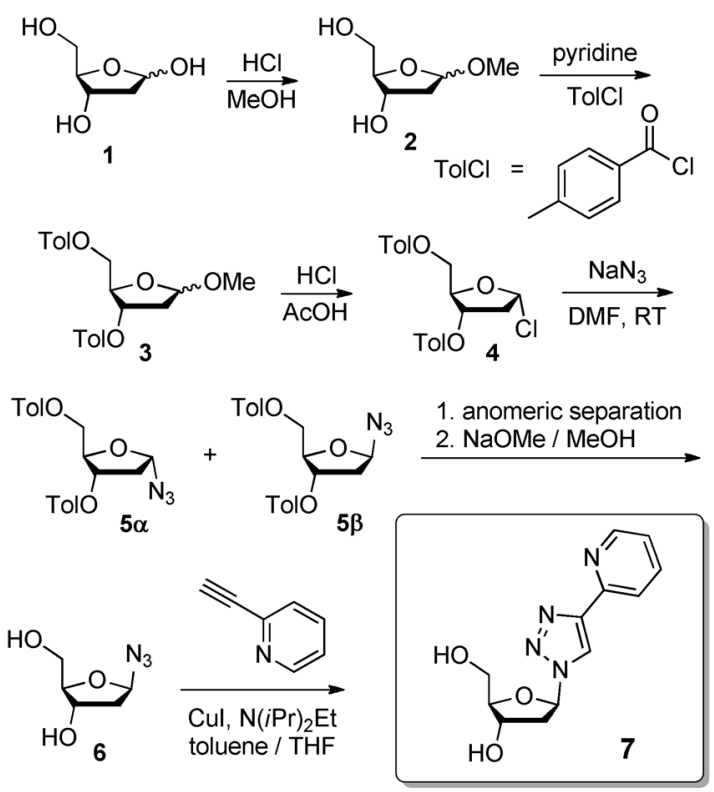

Scheme 1. Synthesis of nucleoside 7.

The methyl protected product $\mathbf{2}$ was treated with para toluo yl chloride in pyridine to protect the $3^{\prime}$ and $5^{\prime}$ hydroxyls. Compound 3 was converted to chloro Hoffer sugar 4 with an $\mathrm{HCl}$ solution in glacial acetic acid generated by adding acetyl chloride to an aqueous solution of acetic acid. The chloro sugar dissolved in $N, N$ dimethylformamide was treat ed with sodium azide to yield the two anomers, $\alpha$ and $\beta$, of protected azido sugar 5. The resulting diastereomeric mix ture was separated by silica gel column chromatography. Deprotection with sodium methoxide in dry methanol af forded azidodeoxyribose 6. Copper catalyzed [3+2] cyclo addition with 2 ethynylpyridine produced 7 after purifica tion by silica gel column chromatography. Ligand 7 recurs in all complexes in this work. $\left.{ }^{[54} 56\right]$

Metallonucleosides were prepared by the treatment of $\mathbf{7}$ with known, chloro bridged iridium(III) dimers. An example appears in Scheme 2. Ambient workup and precipitation yielded the products as analytically pure solids in isolated yields ranging from $6279 \%$. Scheme 3 enumerates the non nucleoside ligands.

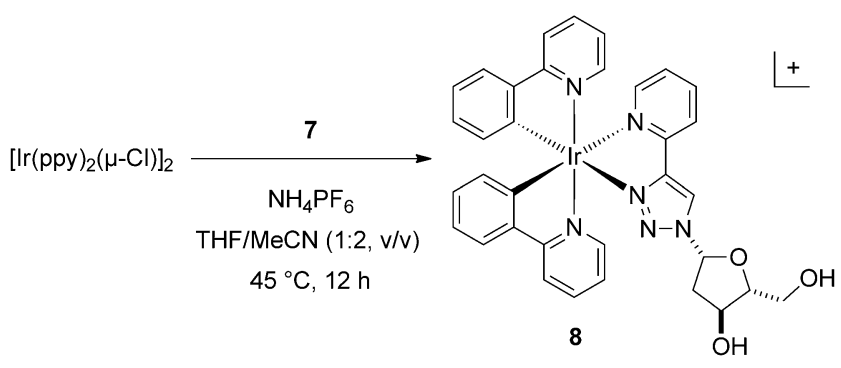

Scheme 2. Synthesis of a typical iridium(III) metallonucleoside.<smiles>Cc1ccccc1-c1ccccn1</smiles>

ppy<smiles>Cc1ccc(-c2ccccn2)c(C)c1</smiles>

tpy<smiles>Cc1cccc2ccc3cccnc3c12</smiles>

bzq

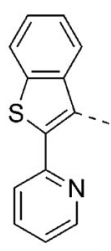

btp<smiles>Cc1ccccc1-c1ccc2c(n1)CCC=C2</smiles>

pq
Scheme 3. Cyclometalating ligands.

Vapor diffusion of pentane into a chloroform solution af forded diffraction quality single crystals of $\left[\operatorname{Ir}(\mathrm{ppy})_{2}(7)\right]$ $\left(\mathrm{PF}_{6}\right)$. A thermal ellipsoid depiction appears in Figure 1. Iri dium carbon bond lengths are 2.017(4) and 2.019(7) $\AA$; the nucleoside pyridyl and triazolyl nitrogen donors exert simi lar trans influences. Iridium pyridyl nitrogen bond lengths are 2.047(5) and 2.048(6) $\AA$ for the 2 phenylpyridine ligands, and 2.163(5) $\AA$ for the nucleoside. The Ir $\mathrm{N}_{\text {triazolyl }}$ distance is 2.141(4) $\AA$, also reflecting a trans disposition to carbon. Counterion and intraligand metrics, including those of the sugar, are unexceptional.

New complexes were characterized by absorption and lu minescence spectroscopies. Absorption features appear in the visible region from about $250435 \mathrm{~nm}$, with more intense bands in the ultraviolet. The weaker, longer wavelength fea tures have been ascribed to spin allowed and spin forbidden metal to ligand charge transfer (MLCT) transitions, ${ }^{[57]}$ and the more intense bands of shorter wavelength to ligand $\pi^{*} \leftarrow \pi$ transitions. Such absorption features are common place among $\mathrm{C}^{\wedge} \mathrm{N}$ chelated complexes of iridium(III). ${ }^{[58]}$

Luminescence: The new complexes emit in fluid solution and in low temperature glasses. Normalized emission spec tra at $77 \mathrm{~K}$ appear in Figure 2; emission maxima and life times are gathered in Table 1 . The cyclometalating ligands modulate the luminescence; emission colors span the visible 


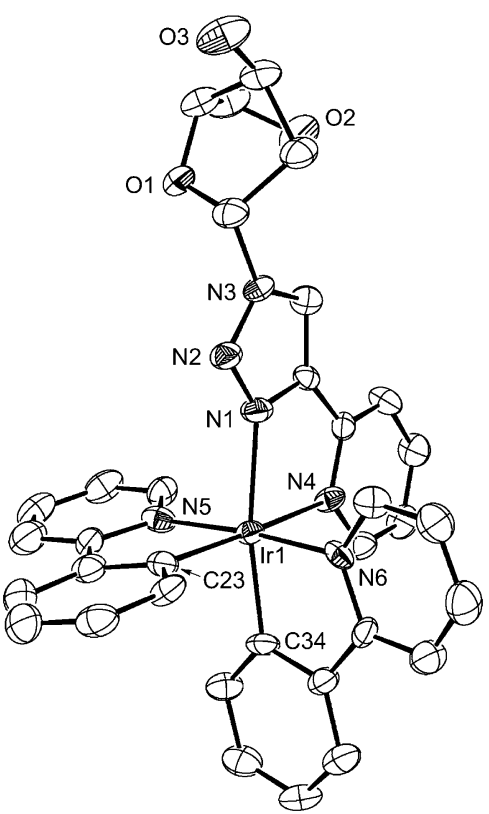

Figure 1. Thermal ellipsoid representation $(50 \%$ probability $)$ of the cation of $\left[\operatorname{Ir}(\mathrm{ppy})_{2}(\mathbf{7})\right]\left(\mathrm{PF}_{6}\right)(\mathbf{8})$ along $c$. Hydrogen atoms and counterion are omitted for clarity. A partial atom labeling scheme is indicated. Se lected interatomic distances $[\AA]$ : Ir1 C34, 2.017(4); Ir1 C23, 2.019(7); Ir1 N6, 2.047(5); Ir1 N5, 2.048(6); Ir1 N1, 2.141(4); Ir1 N4, 2.163(5). Selected angles [ ${ }^{\circ}$ ]: N1 Ir1 N4, 76.7(3); C23 Ir1 N5, 80.2(3).

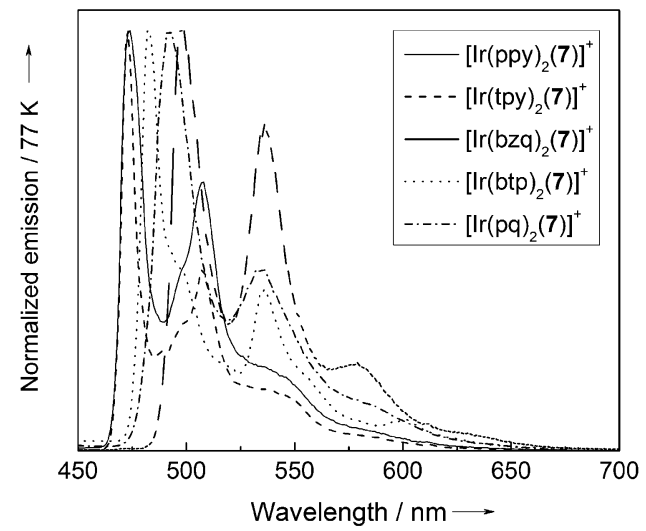

Figure 2. Normalized emission spectra $(77 \mathrm{~K})$ of new complexes in 2 methyltetrahydrofuran glass.

Table 1. Emission wavelengths $\left(\lambda_{\mathrm{em}}\right)$, lifetimes $(\tau)$, and quantum yields $\left(\phi_{\mathrm{em}}\right)$ of iridium(III) complexes as $\mathrm{PF}_{6}$ salts at 295 and $77 \mathrm{~K}$ in 2 methyl tetrahydrofuran.

\begin{tabular}{lllllc}
\hline Sample & \multicolumn{3}{c}{$295 \mathrm{~K}$} & \multicolumn{2}{c}{$77 \mathrm{~K}$} \\
& $\lambda_{\mathrm{em}}[\mathrm{nm}]$ & $\tau[\mu \mathrm{s}]$ & $\phi_{\mathrm{em}}{ }^{\mathrm{a}]}$ & $\lambda_{\mathrm{em}}[\mathrm{nm}]$ & $\tau[\mu \mathrm{s}]$ \\
\hline$\left[\operatorname{Ir}(\mathrm{ppy})_{2}(\mathbf{7})\right]^{+}$ & 475 & 1.5 & 0.15 & 475 & 4.4 \\
{$\left[\operatorname{Ir}(\mathrm{tpy})_{2}(\mathbf{7})\right]^{+}$} & 475 & 1.6 & 0.13 & 475 & 5.8 \\
{$\left[\operatorname{Ir}(\mathrm{bzq})_{2}(\mathbf{7})\right]^{+}$} & 520 & 6.8 & 0.026 & 500 & 62 \\
{$\left[\operatorname{Ir}(\mathrm{btp})_{2}(\mathbf{7})\right]^{+}$} & 592 & 7.2 & 0.044 & 582 & 13 \\
{$\left[\operatorname{Ir}(\mathrm{pq})_{2}(\mathbf{7})\right]^{+}$} & 565 & 1.2 & 0.064 & 542 & 4.6 \\
\hline
\end{tabular}

$[\mathrm{a}] \pm 10 \%$; absorbance of solutions was $\leq 0.1$.

spectrum. Vibronic structure is pronounced. Their microsec ond scale emission lifetimes indicate phosphorescence.
Taken together, the spectra indicate emitting states of con siderable ligand character, with origins that range from ${ }^{3}$ MLCT to ligand centered.

Calculations: The complex $\left[\operatorname{Ir}(\mathrm{btp})_{2}(\mathbf{7})\right]^{+}$was selected for density functional theory calculations because of its long wavelength emission, which minimizes interference from cellular autofluorescence. A frontier Kohn Sham orbital energy level diagram is shown in Figure 3 a with selected or bital depictions in Figure $3 \mathrm{~b}$. The highest occupied Kohn

(a)
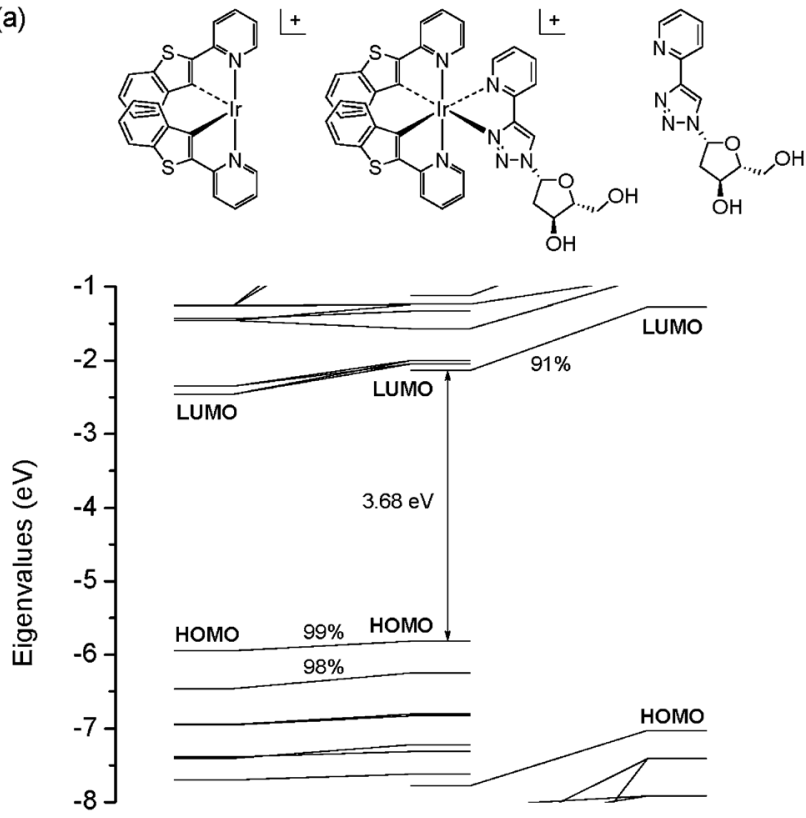

(b)
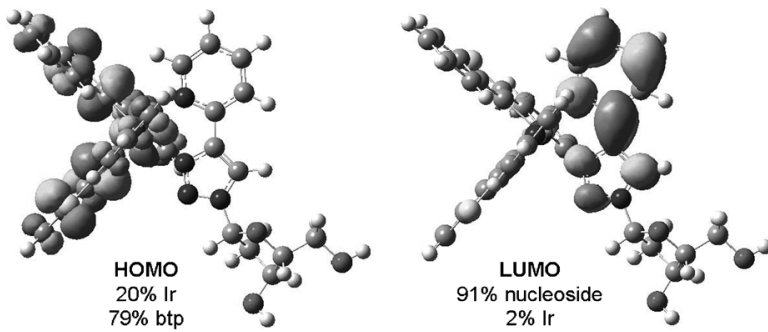

Figure 3. a) Frontier Kohn Sham orbital energy level diagram of $\left[\operatorname{Ir}(\mathrm{btp})_{2}(\mathbf{7})\right]^{+}$. Continuum water solvation is included. b) Plots of selected orbitals (isodensity level is 0.03 a.u.). A color depiction of this Figure ap pears as the Supporting Information.

Sham orbital (HOMO) is delocalized over iridium $(20 \%)$ and the cyclometalating btp ligands $(79 \%)$; percentages are of electron density as calculated by a Mulliken population analysis. ${ }^{[59]}$ The lowest unoccupied Kohn Sham orbital (LUMO) concentrates (91\%) on the pyridyl triazolyl arm. Because the LUMO resides on the ancillary (pyridyl tria zolyl) ligand, the red shifted absorption profile is attributa ble to high energy, occupied btp $\pi$ orbitals.

Cellular uptake of 8: Transport of compound 8 into KB3 1 cells was evaluated using fluorescence microscopy analysis. 
In these experiments, human epidermal carcinoma cells, KB3 1, were treated with a fixed concentration $(50 \mu \mathrm{M})$ of $\mathbf{8}$, and images of treated cells were taken at variable time points using an excitation wavelength of $315 \mathrm{~nm}$ and an emission wavelength of $510 \mathrm{~nm}$. To provide higher quality images, cells were also stained with Hoechst 33342 to stain their nuclei, which appeared blue (excitation wavelength of $340 \mathrm{~nm}$ and an emission wavelength of $480 \mathrm{~nm}$ ). Images pro vided in Figure 4 a show an increase in green fluorescence signal that, in some cases, appears to co localize with the nuclei. In addition, the increase in green fluorescence signal that reflects intracellular accumulation of $\mathbf{8}$ in KB3 1 cells occurs in a time dependent manner, reaching a maximal amount in $24 \mathrm{~h}$.

The dose dependency of the uptake of $\mathbf{8}$ was similarly evaluated. In these experiments, KB3 1 cells were treated the fluorescent analogue. This nucleoside acts as a substrate for all nucleoside transporters, including hENT and hCNT family members, ${ }^{[6065]}$ and should thus function as a broad spectrum inhibitor for the uptake of $\mathbf{8}$. Cells were treated with DMSO (vehicle) or $2^{\prime}$ deoxyadenosine (10 or $\left.200 \mu \mathrm{M}\right)$ for $24 \mathrm{~h}$ prior to treatment with 10 or $50 \mu \mathrm{M}$ of compound $\mathbf{8}$. Data provided in Figure 5 show that the inclusion of $10 \mu \mathrm{m}$ $2^{\prime}$ deoxyadenosine exerts little effect on the uptake of either low $(10 \mu \mathrm{M})$ or high $(50 \mu \mathrm{M})$ concentrations of 8 . In contrast, pretreatment with $200 \mu \mathrm{M} 2^{\prime}$ deoxyadenosine attenuates the phosphorescence signal caused by the uptake of $\mathbf{8}$. The abili ty of high concentrations of 2 ' deoxyadenosine to block uptake suggests that the transport of $\mathbf{8}$ is catalyzed by one or more hENT family members. This suggestion is based on the fact that hENT family members have weaker affinity for natural nucleosides, such as 2 deoxyadenosine, compared to hCNTs. ${ }^{[66,67]}$

The accumulation of $\mathbf{8}$ in KB3 1 cells was also quantified using a plate reader assay. KB3 1 cells were seeded onto 12 well plates at a density of 200000 cells per well. After overnight incubation to allow cell attachment, the cells were treated with variable concentra tions of $\mathbf{8}$ for an additional $48 \mathrm{~h}$. After $48 \mathrm{~h}$, the medium containing $\mathbf{8}$ was removed, and the cells were washed twice with $200 \mu \mathrm{L}$ of phosphate buf fered saline (PBS). Each wash ing step was performed for $10 \mathrm{~min}$ at $37^{\circ} \mathrm{C}$. All washes were collected and analyzed as described in the Experimental

Figure 4. a) Time dependent accumulation of $\mathbf{8}$ into human epidermal carcinoma cell lines, KB3 1. Images of cells treated with $50 \mu \mathrm{M}$ of $\mathbf{8}$ were taken $4,8,12$, and 24 h post treatment. b) Dose dependent accumulation of $\mathbf{8}$ into KB3 1 cells. Cells were incubated with 10 and $50 \mu \mathrm{M}$ of $\mathbf{8}$ for $24 \mathrm{~h}$. Compound $\mathbf{8}$ shows green fluores cence whereas the nuclei are stained with Hoechst 33342 (blue). Scale bars $(100 \mu \mathrm{m})$ are provided for refer ence.

with variable concentrations of compound $\mathbf{8}$ for a fixed time in terval $(24 \mathrm{~h})$. Representative data in Figure 4b show that KB3 1 cells treated with $50 \mu \mathrm{M}$ 8 show more intense phosphor escence than cells treated with $10 \mu \mathrm{M} \mathrm{8}$. As before, the higher emission intensity reflects intra cellular accumulation of $\mathbf{8}$ that occurs in a dose dependent manner.

We next evaluated if the uptake of $\mathbf{8}$ occurs by passive diffusion or by the activity of one or more nucleoside trans porters. This was accomplished by quantifying the ability of the natural nucleoside, $2^{\prime}$ deoxyade nosine, to block the uptake of
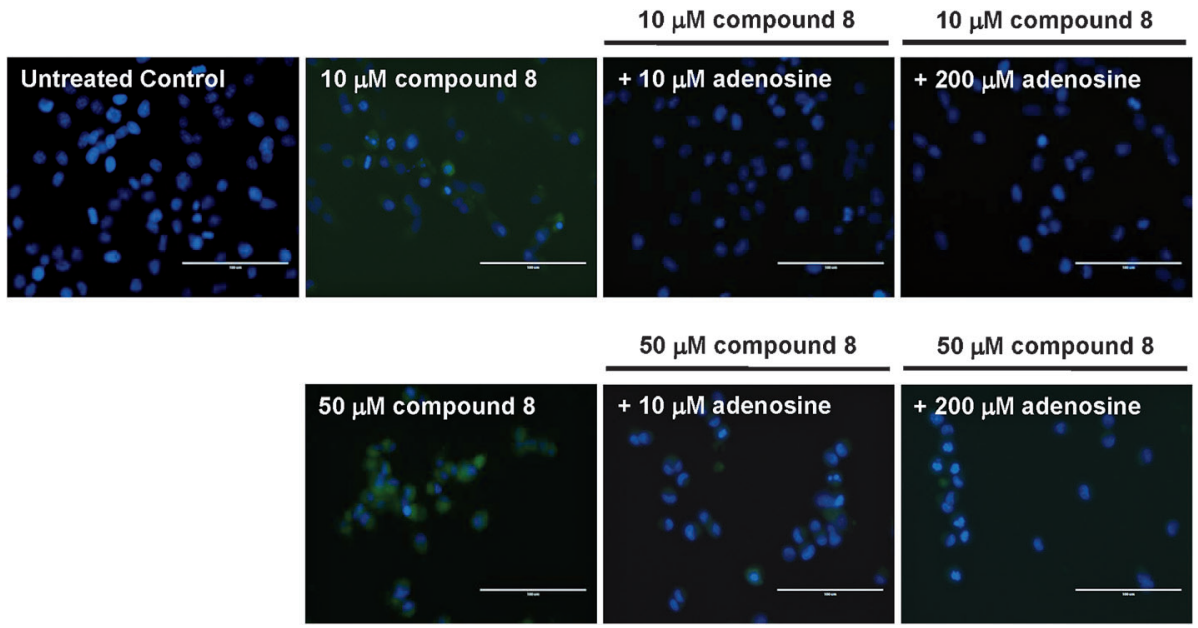

Figure 5. The uptake of $\mathbf{8}$ is dependent on nucleoside transporter activity. KB3 1 cells were treated with varia ble concentration of $\mathbf{8}(10$ and $50 \mu \mathrm{M})$ in the absence and presence of increasing concentrations of $2^{\prime}$ deoxyade nosine. Cell images were taken after $24 \mathrm{~h}$ of exposure to $\mathbf{8}$. Compound $\mathbf{8}$ shows green fluorescence whereas nuclei are stained with Hoechst 33342 (blue). Scale bars $(100 \mu \mathrm{m})$ are provided for reference. 
Section to measure the concentration of unbound 8 . The cells were then treated with $0.25 \%$ trypsin and harvested by centrifugation. The supernatant was removed, and the cells were again washed with $1 \mathrm{~mL}$ of $\mathrm{PBS}$ at $37^{\circ} \mathrm{C}$ to remove un bound and bound nucleoside. After this last wash step, the cells were lysed using $0.1 \%$ Triton X 100 in $1 \times$ PBS. The amount of $\mathbf{8}$ present in the lysate was then measured using a fluorescent plate reader $\left(\lambda_{\mathrm{ex}}=340 \mathrm{~nm} / \lambda_{\mathrm{em}}=480 \mathrm{~nm}\right)$. The data provided in Figure 6 show a dependency on the fluores cence signal as a function of the concentration of $\mathbf{8}$, thus val idating that $\mathbf{8}$ accumulates inside KB3 1 cells.

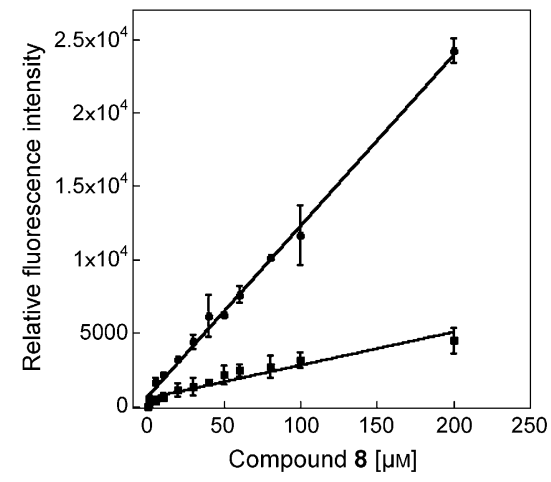

Figure 6. Quantifying the cellular accumulation of compound 8 in KB3 1 cells. Cells were treated with variable concentrations of 8 for $48 \mathrm{~h}$ and the fluorescence intensities of lysed cells were measured with a fluores cence plate reader. Data points for lysed KB3 1 cells are provided as cir cles and data points for the collected supernatants are provided as squares. These experiments represent an average of three or four inde pendent experiments performed on different days. The error bars repre sent standard deviations.

\section{Conclusion}

Described herein is a synthetic strategy with which deoxyri bose sugars are linked to chelating pyridyl triazoles. An effi cient method has been developed that attaches these sugar bearing ligands to cyclometalated iridium(III). The resulting assemblies are luminescent. Choice of the cyclometalating $\mathrm{C}^{\wedge} \mathrm{N}$ ligand controls emission colors, and lumophores of many hues can be prepared.

Membrane bound enzymes translocate nucleosides from extracellular space into the cytosol in the first step of nu cleoside metabolism. Most nucleoside transport enzymes support sweeping variations in the nucleobase. The pendant (deoxy)sugar is the recognition site of nucleoside substrates. Chemical tags that monitor nucleoside transport are few, and studies of transport in vivo are hindered. The conjugates herein join an emissive complex to a deoxyribose sugar. They are potential photoactive surrogates of natural nucleo sides; their biodisposition can be tracked optically. These studies are in progress.

\section{Experimental Section}

Materials and methods: Experimental procedures involving air or mois ture sensitive substances were performed under argon using either Schlenk line techniques or in a nitrogen filled MBraun drybox. Anhy drous solvents were used directly from an MBraun solvent purification system or were purchased from Sigma Aldrich. ${ }^{1} \mathrm{H}$ NMR experiments were performed on a Varian 400 FT NMR spectrometer operating at $399.7 \mathrm{MHz} .{ }^{1} \mathrm{H}$ chemical shifts are reported in parts per million $(\delta)$, mea sured from tetramethylsilane $(0 \mathrm{ppm})$ and are referenced to residual sol vent in $\mathrm{CDCl}_{3}(7.26 \mathrm{ppm}),\left[\mathrm{D}_{6}\right]$ acetone $(2.05 \mathrm{ppm})$ or $\mathrm{CD}_{2} \mathrm{Cl}_{2}(5.32 \mathrm{ppm})$ for ${ }^{1} \mathrm{H}$ NMR. ${ }^{13} \mathrm{C}\left\{{ }^{1} \mathrm{H}\right\}$ NMR spectra were recorded on a Varian INOVA AS 600 spectrometer operating at $150.0 \mathrm{~Hz} .{ }^{13} \mathrm{C}$ NMR chemical shifts are reported in parts per million $(\delta)$, measured from tetramethylsilane $(0 \mathrm{ppm})$ and are referenced to solvent residuals in $\mathrm{CDCl}_{3}(77.00 \mathrm{ppm})$ or $\mathrm{CD}_{2} \mathrm{Cl}_{2}(54.00 \mathrm{ppm})$. The configuration of the nucleoside was confirmed by ${ }^{1} \mathrm{H}$ NMR NOE difference spectroscopy on a Varian INOVA AS 600 instrument. High resolution electrospray ionization mass spectrometry (Hi Res ESI MS) experiments were performed on an IonSpec HiRes ESI FTICRMS at the University of Cincinnati Mass Spectrometry facili ty. Solvents were degassed by bubbling argon for $20 \mathrm{~min}$ prior to use for $\mathrm{UV} / \mathrm{Vis}$ and luminescence measurements. UV/Vis and luminescence data were recorded using a Cary $5 \mathrm{G}$ UV/Vis/NIR spectrometer and a Cary Eclipse spectrometer, respectively. Thin layer chromatography (TLC) was carried out using Whatman silica gel UV254 plates. Column chroma tography was performed using Fisher Scientific silica gel, sizes 32 63. El emental analyses were carried out by Robertson Microlit Laboratories, Ledgewood, NJ.

Chemicals from commercial sources were used as received. 2 Deoxy D ribose, pyridine, $p$ toluoyl chloride, acetyl chloride, 2 ethoxyethanol, and sodium methoxide (NaOMe) were purchased from Acros Organics. Sodium azide $\left(\mathrm{NaN}_{3}\right), N, N$ diisopropylethylamine (DIPEA) and cop per(I) iodide $(\mathrm{CuI})$ were purchased from Sigma Aldrich. Iridium(III) chloride $\left(\mathrm{IrCl}_{3} \cdot 3 \mathrm{H}_{2} \mathrm{O}\right)$ and ammonium hexafluorophosphate $\left(\mathrm{NH}_{4} \mathrm{PF}_{6}\right)$ were purchased from Strem Chemicals.

Hoffer's $\alpha$ chlorosugar (1 $\alpha$ chloro 3,5 di $(O p$ toluoyl $) 2$ deoxy D ribose) was synthesized with a slight modification of the first step of an established procedure ${ }^{[68]}$ in which an equivalent amount of concentrated hydrochloric acid was used in place of dissolving hydrogen chloride gas in methanol. Cyclometalated $\operatorname{Ir}^{\mathrm{III}} \mu$ chloro bridged dimers, $\left(\mathrm{C}^{\wedge} \mathrm{N}\right)_{2} \operatorname{Ir}(\mu$ $\mathrm{Cl})_{2} \operatorname{Ir}\left(\mathrm{C}^{\wedge} \mathrm{N}\right)_{2}\left(\right.$ abbreviated as $\left.\left[\left\{\operatorname{Ir}\left(\mathrm{C}^{\wedge} \mathrm{N}\right)_{2}(\mu \mathrm{Cl})\right\}_{2}\right]\right)$, were synthesized with the method reported by Nonoyama; $;{ }^{[69]} \mathrm{IrCl}_{3} \cdot 3 \mathrm{H}_{2} \mathrm{O}$ was refluxed with 2 2.5 equiv cyclometalating ligand in a 3:1 mixture of 2 ethoxyethanol and water. Synthesis and characterization of $\left[\left\{\operatorname{Ir}(\mathrm{ppy})_{2}(\mu \mathrm{Cl})\right\}_{2}\right],{ }^{[70]}\left[\left\{\operatorname{Ir}(\mathrm{tpy})_{2}\right.\right.$ $\left.(\mu \mathrm{Cl})\}_{2}\right],{ }^{[71]}\left[\left\{\operatorname{Ir}(\mathrm{bzq})_{2}(\mu \mathrm{Cl})\right\}_{2}\right],{ }^{[72]}\left[\left\{\operatorname{Ir}(\mathrm{pq})_{2}(\mu \mathrm{Cl})\right\}_{2}\right],{ }^{[73]}$ and $\left[\left\{\operatorname{Ir}(\mathrm{btp})_{2}(\mu\right.\right.$ $\left.\mathrm{Cl})\}_{2}\right]^{[74]}$ were reported previously.

1-ק-Azido-3,5-di-( $\boldsymbol{O}$-p-toluoyl)-2-deoxy-D-ribose $\quad(\mathbf{5} \boldsymbol{\beta}): \mathrm{NaN}_{3} \quad(0.390 \mathrm{~g}$, $5.99 \mathrm{mmol})$ was added to a mixture of $\alpha$ chlorosugar 4 (1.50 g, $3.85 \mathrm{mmol})$ in dry DMF $(50 \mathrm{~mL})$, stirred at RT for $30 \mathrm{~min}$. The mixture was vigorously stirred at RT for $2 \mathrm{~h}$ in an inert atmosphere as the reac tion was tracked by TLC. After completion of the reaction, EtOAc $(100 \mathrm{~mL})$ was added to the mixture to form a uniform organic layer. The organic layer was washed with water $(2 \times 100 \mathrm{~mL})$ followed by brine $(150 \mathrm{~mL})$ and dried (over anhydrous $\mathrm{Na}_{2} \mathrm{SO}_{4}$ ). Evaporation under re duced pressure afforded the crude product mixture $(1.4 \mathrm{~g}, 92 \%, \beta / \alpha$ $\approx 1: 1$ ), which was resolved by chromatography using diethyl ether/hex anes $(1: 9 \mathrm{v} / \mathrm{v})$ mixture. Compound $\mathbf{5} \boldsymbol{\beta}$ was eluted as the first fraction. Yield: $0.823 \mathrm{~g}(54 \%) ; \quad R_{\mathrm{f}}=\beta$ : 0.55 (diethyl ether/hexanes =30:70); ${ }^{1} \mathrm{H}$ NMR $\left(400 \mathrm{MHz}, \mathrm{CDCl}_{3}\right): \delta=7.97(\mathrm{~d}, 2 \mathrm{H}, J=8.1 \mathrm{~Hz}), 7.89(\mathrm{~d}, 2 \mathrm{H}, J=$ $8.2 \mathrm{~Hz}), 7.247 .21(\mathrm{~m}, 4 \mathrm{H}), 5.70(\mathrm{t}, 1 \mathrm{H}, J=5.2 \mathrm{~Hz}), 5.56(\mathrm{td}, 1 \mathrm{H}, J=5.5$, $2.4 \mathrm{~Hz}), 4.594 .50(\mathrm{~m}, 3 \mathrm{H}), 2.422 .39 \mathrm{ppm}(\mathrm{m}, 8 \mathrm{H})$; HRMS: calcd for $\mathrm{C}_{21} \mathrm{H}_{21} \mathrm{~N}_{3} \mathrm{NaO}_{5}[M+\mathrm{Na}]^{+}$: 418.1379 ; found: 418.1376.

1- $\alpha$-Azido-3,5-di-(O-p-toluoyl)-2-deoxy-D-ribose $(\mathbf{5} \boldsymbol{\alpha})$ : Collected as the second fraction from the column. Yield: $0.7 \mathrm{~g}(46 \%) ; R_{\mathrm{f}}=\alpha: 0.48$ (diethyl ether/hexanes $=30: 70) ;{ }^{1} \mathrm{H}$ NMR $\left(400 \mathrm{MHz}, \mathrm{CDCl}_{3}\right): \delta=7.96(\mathrm{~d}, 2 \mathrm{H}, J=$ $8.3 \mathrm{~Hz}), 7.91(\mathrm{~d}, 2 \mathrm{H}, J=8.2 \mathrm{~Hz}), 7.277 .23(\mathrm{~m}, 4 \mathrm{H}), 5.71(\mathrm{~d}, 1 \mathrm{H}, J=$ $5.6 \mathrm{~Hz}), 5.515 .48(\mathrm{~m}, 1 \mathrm{H}), 4.72(\mathrm{q}, 1 \mathrm{H}, J=3.8 \mathrm{~Hz}), 4.634 .50(\mathrm{~m}, 2 \mathrm{H})$, 
$2.582 .52(\mathrm{~m}, 1 \mathrm{H}), 2.42(\mathrm{~s}, 3 \mathrm{H}), 2.41(\mathrm{~s}, 3 \mathrm{H}), 2.252 .21 \mathrm{ppm}(\mathrm{m}, 1 \mathrm{H})$; HRMS: calcd for $\mathrm{C}_{21} \mathrm{H}_{21} \mathrm{~N}_{3} \mathrm{NaO}_{5}[M+\mathrm{Na}]^{+}$: 418.1379; found: 418.1366.

1-ß-Azido-2-deoxy-D-ribose (6): Dry $\mathrm{MeOH}(50 \mathrm{~mL})$ followed by sodium methoxide $(0.410 \mathrm{~g}, 7.58 \mathrm{mmol})$ were added to a dry round bottom flask loaded with $\mathbf{5 \beta}(0.950 \mathrm{~g}, 2.4 \mathrm{mmol})$. The reaction mixture was stirred under inert atmosphere at RT for $24 \mathrm{~h}$ and monitored by TLC. After this time, the solvent was removed under vacuum. The residue was loaded on a silica gel column, and the desired product 6 was isolated when eluted with $5 \% \mathrm{MeOH}$ in diethyl ether. Yield: $0.310 \mathrm{~g}(81 \%) ; R_{\mathrm{f}}=0.60$ (metha nol/diethyl ether $=5: 95) ;{ }^{1} \mathrm{H} \mathrm{NMR}\left(400 \mathrm{MHz}, \mathrm{CDCl}_{3}\right): \delta=5.55(\mathrm{t}, 1 \mathrm{H}$, $J=4.0 \mathrm{~Hz}), 4.39(\mathrm{~d}, 1 \mathrm{H}, J=4.8 \mathrm{~Hz}), 3.953 .92(\mathrm{~m}, 1 \mathrm{H}), 3.753 .66(\mathrm{~m}$, $2 \mathrm{H}), 2.152 .11 \mathrm{ppm}(\mathrm{m}, 2 \mathrm{H})$; HRMS: calcd for $\mathrm{C}_{5} \mathrm{H}_{9} \mathrm{~N}_{3} \mathrm{NaO}_{3}[M+\mathrm{Na}]^{+}$: 182.0542; found: 182.0545

1-(1'-\$-2'-Deoxy-D-ribofuranosyl)-4-(5-(2-pyridinyl))-1,2,3-triazole (7): Compound $6(0.540 \mathrm{~g}, 3.39 \mathrm{mmol})$ was dissolved in a mixture of THF $(10 \mathrm{~mL})$ and toluene $(40 \mathrm{~mL}) .2$ Ethynylpyridine $(0.54 \mathrm{~mL}, 5.35 \mathrm{mmol})$, DIPEA $(2.7 \mathrm{~mL}, 15.5 \mathrm{mmol})$, and $\mathrm{CuI}(0.646 \mathrm{~g}, 3.39 \mathrm{mmol})$ were added to the reaction mixture. The solution was heated to reflux. The reaction was complete after $24 \mathrm{~h}$, as monitored by TLC. The solvent was removed by rotary evaporation. The crude reaction mixture was loaded on a silica gel column packed with $1: 1 \mathrm{v} / \mathrm{v}$ diethyl ether/hexanes. The desired prod uct 7 was isolated when the eluant polarity was increased to $1: 9 \mathrm{v} / \mathrm{v}$ $\mathrm{MeOH} /$ diethyl ether. Yield: $0.665 \mathrm{~g}(75 \%) ; R_{\mathrm{f}}=0.20$ (methanol/diethyl ether $=5: 95) ;{ }^{1} \mathrm{H}$ NMR $\left(400 \mathrm{MHz}, \mathrm{CDCl}_{3}\right): \delta=8.49(\mathrm{~d}, 1 \mathrm{H}, J=4.0 \mathrm{~Hz})$, $8.46(\mathrm{~s}, 1 \mathrm{H}), 8.09(\mathrm{~d}, 1 \mathrm{H}, J=8.3 \mathrm{~Hz}), 7.77(\mathrm{td}, 1 \mathrm{H} . J=6.0,1.6 \mathrm{~Hz}), 7.24$ $7.21(\mathrm{~m}, 1 \mathrm{H}), 6.42\left(\mathrm{t}_{\text {app }}\right.$, characteristic peak for $\beta$ anomer, $\left.1 \mathrm{H}, J=6.7 \mathrm{~Hz}\right)$, $4.77(\mathrm{~d}, 1 \mathrm{H}, J=4.8 \mathrm{~Hz}), 4.13(\mathrm{~d}, 1 \mathrm{H}, J=3.9 \mathrm{~Hz}), 3.883 .72(\mathrm{~m}, 2 \mathrm{H}), 2.89$ $2.83(\mathrm{~m}, 1 \mathrm{H}), 2.632 .57 \mathrm{ppm}(\mathrm{m}, 1 \mathrm{H}) ;{ }^{13} \mathrm{C}$ NMR $\left(150 \mathrm{MHz}, \mathrm{CDCl}_{3}\right): \delta=$ 149.72, 149.23, 148.03, 137.24, 123.14, 121.53, 120.43, 88.96, 88.39, 71.69, 62.61, 41.67 ppm; HRMS: calcd for $\mathrm{C}_{12} \mathrm{H}_{14} \mathrm{~N}_{4} \mathrm{NaO}_{3}[M+\mathrm{Na}]^{+}$: 285.0964; found: 285.0974; elemental analysis calcd for $\mathrm{C}_{12} \mathrm{H}_{14} \mathrm{~N}_{4} \mathrm{O}_{3}$ : C 54.96, $\mathrm{H}$ 5.38, N 21.36; found: C 55.12, H 5.42, N 21.34.

[Ir(ppy) $\left.)_{2}(\mathbf{7})\right] \mathbf{P F}_{\mathbf{6}}(\mathbf{8}):\left[\left\{\operatorname{Ir}(\mathrm{ppy})_{2}(\mu \mathrm{Cl})\right\}_{2}\right](0.040 \mathrm{~g}, 0.037 \mathrm{mmol})$ was sus pended in acetonitrile $(20 \mathrm{~mL})$. To this was added a $10 \mathrm{~mL}$ THF solution of compound $7(0.024 \mathrm{~g}, 0.092 \mathrm{mmol})$ followed by $\mathrm{NH}_{4} \mathrm{PF}_{6}(0.012 \mathrm{~g}$, $0.076 \mathrm{mmol})$. After being purged with argon, the reaction mixture was heated to $45^{\circ} \mathrm{C}$ and left to stir for $12 \mathrm{~h}$. The reaction was complete after this time period as indicated by TLC. The solvent was removed under re duced pressure to render a dark orange residue. The crude reaction mix ture was washed with THF, water, and ice cold acetone followed by di ethyl ether and pentane. The product was vacuum dried to give analyti cally pure compound. Yield: $0.053 \mathrm{~g}(75 \%)$; ${ }^{1} \mathrm{H}$ NMR $(400 \mathrm{MHz}$, $\left.\mathrm{CD}_{2} \mathrm{Cl}_{2}\right): \delta=9.23(\mathrm{~d}, 1 \mathrm{H}, J=3.2 \mathrm{~Hz}), 8.25(\mathrm{dd}, 1 \mathrm{H}, J=5.0,4.2 \mathrm{~Hz}), 8.01$ $(\mathrm{t}, 1 \mathrm{H}, J=7.8 \mathrm{~Hz}), 7.957 .92(\mathrm{~m}, 2 \mathrm{H}), 7.83(\mathrm{~d}, 1 \mathrm{H}, J=5.4 \mathrm{~Hz}), 7.817 .76$ $(\mathrm{m}, 2 \mathrm{H}), 7.727 .68(\mathrm{~m}, 3 \mathrm{H}), 7.50(\mathrm{dd}, 1 \mathrm{H}, J=6.3,5.3 \mathrm{~Hz}), 7.29(\mathrm{t}, 1 \mathrm{H}$, $J=7.3 \mathrm{~Hz}), 7.106 .96(\mathrm{~m}, 4 \mathrm{H}), 6.92(\mathrm{t}, 1 \mathrm{H}, J=7.1 \mathrm{~Hz}), 6.86(\mathrm{t}, 1 \mathrm{H}, J=$ $7.6 \mathrm{~Hz}), 6.506 .41(\mathrm{~m}, 1 \mathrm{H}), 6.316 .28(\mathrm{~m}, 2 \mathrm{H}), 4.734 .62(\mathrm{~m}, 1 \mathrm{H}), 4.12$ $4.08(\mathrm{~m}, 1 \mathrm{H}), 3.963 .80(\mathrm{~m}, 2 \mathrm{H}), 2.762 .53 \mathrm{ppm}(\mathrm{m}, 2 \mathrm{H}) ;{ }^{13} \mathrm{C} \mathrm{NMR}$ $\left(150 \mathrm{MHz}, \mathrm{CD}_{2} \mathrm{Cl}_{2}\right): \delta=168.59,167.95,150.83,150.04,149.94,149.82$, $149.22,149.07,146.68,144.56,140.18,138.71,138.64,132.50,132.07$, $131.12,130.43,127.13,125.32,124.92,124.46,124.36,124.13,124.00$, $123.79,123.69,123.31,122.86,120.19,91.88,89.11,70.97,62.04$, $42.82 \mathrm{ppm} ; \quad$ UV/Vis (acetonitrile): $\lambda_{\max } \quad(\varepsilon)=249 \quad(27000), \quad 380 \mathrm{~nm}$ $\left(4000 \mathrm{M}^{1} \mathrm{~cm}^{1}\right)$; emission (acetonitrile): $\lambda_{\mathrm{ex}}$ (Int.) $=478(190), 506 \mathrm{~nm}$

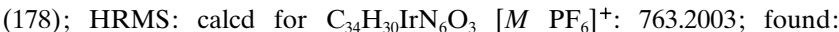
763.2004; elemental analysis calcd for $\mathrm{C}_{34} \mathrm{H}_{30} \mathrm{~F}_{6} \mathrm{IrN}_{6} \mathrm{O}_{3} \mathrm{P}$ : C 44.98, H 3.33, N 9.26; found: C 45.21, H 3.52, N 9.35.

[Ir(tpy) $\left.\mathbf{2}_{2}(\mathbf{7})\right] \mathbf{P F}_{6}:\left[\left\{\operatorname{Ir}(\operatorname{tpy})_{2}(\mu \mathrm{Cl})\right\}_{2}\right](0.046 \mathrm{~g}, 0.041 \mathrm{mmol})$ was suspended in dry acetonitrile $(25 \mathrm{~mL})$. To this was added a solution of compound 7 $(0.026 \mathrm{~g}, 0.099 \mathrm{mmol})$ dissolved in $10 \mathrm{~mL}$ dry THF, followed by $\mathrm{NH}_{4} \mathrm{PF}_{6}$ $(0.014 \mathrm{~g}, 0.086 \mathrm{mmol})$. After being purged with argon, the reaction mix ture was sealed and heated to $45^{\circ} \mathrm{C}$. The reaction was complete after $12 \mathrm{~h}$ as indicated by TLC. The solvent was removed under reduced pres sure to render a dark orange residue. The crude reaction mixture was washed with THF, water and ice cold acetone, followed by diethyl ether and pentane. The remaining product was dried under vacuum to give an alytically pure compound. Yield: $0.047 \mathrm{~g}(62 \%) ;{ }^{1} \mathrm{H}$ NMR $(400 \mathrm{MHz}$, [D $\mathrm{D}_{6}$ ]acetone $): \delta=9.43(\mathrm{~d}, 1 \mathrm{H}, J=5.9 \mathrm{~Hz}), 8.40(\mathrm{dd}, 1 \mathrm{H}, J=5.3,3.2 \mathrm{~Hz})$, $8.19(\mathrm{t}, 1 \mathrm{H}, J=7.8 \mathrm{~Hz}), 8.14(\mathrm{~d}, 2 \mathrm{H}, J=8.3 \mathrm{~Hz}), 7.957 .85(\mathrm{~m}, 4 \mathrm{H}), 7.78$ $7.69(\mathrm{~m}, 3 \mathrm{H}), 7.55(\mathrm{t}, 1 \mathrm{H}, J=5.6 \mathrm{~Hz}), 7.137 .05(\mathrm{~m}, 2 \mathrm{H}), 6.86(\mathrm{~d}, 1 \mathrm{H}, J=$ $7.4 \mathrm{~Hz}), 6.78(\mathrm{~d}, 1 \mathrm{H}, J=7.5 \mathrm{~Hz}), 6.46(\mathrm{q}, 1 \mathrm{H}, J=8.8 \mathrm{~Hz}), 6.176 .14(\mathrm{~m}$ $2 \mathrm{H}), 4.634 .48(\mathrm{~m}, 1 \mathrm{H}), 4.074 .08(\mathrm{~m}, 1 \mathrm{H}), 3.763 .62(\mathrm{~m}, 2 \mathrm{H}), 2.642 .53$ $(\mathrm{m}, 2 \mathrm{H}), 2.08(\mathrm{~s}, 3 \mathrm{H}), 2.05 \mathrm{ppm}(\mathrm{s}, 3 \mathrm{H}) ;{ }^{13} \mathrm{C}$ NMR $\left(150 \mathrm{MHz}, \mathrm{CD}_{2} \mathrm{Cl}_{2}\right)$ $\delta=168.56,167.97,150.83,150.03,149.92,149.85,149.19,148.89,146.81$, $141.91,141.84,141.48,140.69,140.03,138.51,138.45,133.19,132.75$, $127.03,125.21,124.82,124.36,124.29,123.85,123.67,123.52,123.39$, $123.10,119.79,91.76,89.10,70.78,61.92,42.78,22.05 \mathrm{ppm}\left(2 \mathrm{CH}_{3} \mathrm{C}\right)$; UV/Vis (acetonitrile): $\lambda_{\max }(\varepsilon)=249(15000), 267($ sh, 14000), $378 \mathrm{~nm}$ $\left(3000 \mathrm{M}^{1} \mathrm{~cm}^{1}\right)$; emission (acetonitrile): $\lambda_{\text {ex }}($ Int.) $=480(160), 508 \mathrm{~nm}$ (147); HRMS: calcd for $\mathrm{C}_{36} \mathrm{H}_{34} \mathrm{IrN}_{6} \mathrm{O}_{3}\left[\begin{array}{ll}M & \mathrm{PF}_{6}\end{array}\right]^{+}$: 791.2316; found: 791.2320; elemental analysis calcd for $\mathrm{C}_{36} \mathrm{H}_{34} \mathrm{~F}_{6} \operatorname{IrN}_{6} \mathrm{O}_{3} \mathrm{P}: \mathrm{C} 46.20, \mathrm{H} 3.66$, N 8.98; found: C 46.51, H 3.85, N 9.21.

[Ir(bzq) $\left.)_{2}(\mathbf{7})\right] \mathbf{P F}_{6}:\left[\left\{\operatorname{Ir}(\mathrm{bzq})_{2}(\mu \mathrm{Cl})\right\}_{2}\right](0.045 \mathrm{~g}, 0.038 \mathrm{mmol})$ was suspended in dry acetonitrile $(20 \mathrm{~mL})$. To this was added a $10 \mathrm{~mL}$ THF solution of compound $7(0.025 \mathrm{~g}, 0.096 \mathrm{mmol})$ followed by $\mathrm{NH}_{4} \mathrm{PF}_{6} \quad(0.016 \mathrm{~g}$, $0.096 \mathrm{mmol}$ ). The reaction mixture was purged with argon, heated to $45^{\circ} \mathrm{C}$, and left to stir for $12 \mathrm{~h}$. The reaction was complete after this time period as indicated by TLC. The solvent was removed under reduced pressure to render a dark orange residue. The crude reaction mixture was washed with THF, water, and ice chilled methanol, followed by di ethyl ether and pentane. The product was vacuum dried to give analyti cally pure compound. Yield: $0.058 \mathrm{~g}(79 \%) ;{ }^{1} \mathrm{H}$ NMR $(400 \mathrm{MHz}$, $\left.\mathrm{CD}_{2} \mathrm{Cl}_{2}\right): \delta=9.48(\mathrm{~d}, 1 \mathrm{H}, J=13.7 \mathrm{~Hz}), 8.318 .29(\mathrm{~m}, 3 \mathrm{H}), 8.06(\mathrm{ddd}, 1 \mathrm{H}$, $J=8.9,5.3,1.2 \mathrm{~Hz}), 7.917 .85(\mathrm{~m}, 4 \mathrm{H}), 7.78(\mathrm{t}, 1 \mathrm{H}, J=6.5 \mathrm{~Hz}), 7.727 .68$ (m, 2H), $7.51(\mathrm{~d}, 1 \mathrm{H}, J=7.6 \mathrm{~Hz}), 7.477 .37(\mathrm{~m}, 3 \mathrm{H}), 7.187 .12(\mathrm{~m}, 2 \mathrm{H})$, $7.10(\mathrm{td}, 1 \mathrm{H}, J=7.2,1.4 \mathrm{~Hz}), 6.406 .24(\mathrm{~m}, 3 \mathrm{H}), 4.794 .62(\mathrm{~m}, 1 \mathrm{H}), 3.98$ $3.94(\mathrm{~m}, 1 \mathrm{H}), 3.853 .82(\mathrm{~m}, 2 \mathrm{H}), 2.702 .36 \mathrm{ppm}(\mathrm{m}, 2 \mathrm{H}) .{ }^{13} \mathrm{C}$ NMR $\left(150 \mathrm{MHz}, \mathrm{CD}_{2} \mathrm{Cl}_{2}\right): \delta=158.10,157.52,151.21,150.41,149.44,149.06$, $148.37,148.13,146.42,143.19,141.57,141.32,140.15,137.70,134.86$, $134.56,130.50,130.39,130.29,129.83,129.74,129.41,127.79,126.92$, $124.88,124.44,124.10,123.85,122.95,122.74,122.37,121.30,120.80,91.60$, $88.92,69.79,61.11,42.43 \mathrm{ppm}$; UV/Vis (acetonitrile): $\lambda_{\max }(\varepsilon)=242$ (14000), $315 \mathrm{~nm}\left(8000 \mathrm{~m}^{1} \mathrm{~cm}^{1}\right)$; emission (acetonitrile): $\lambda_{\mathrm{ex}}$ (Int.) $=516$ (176), $540 \mathrm{~nm}$ (sh, 150); HRMS: calcd for $\mathrm{C}_{38} \mathrm{H}_{30} \mathrm{IrN}_{6} \mathrm{O}_{3}\left[M \mathrm{PF}_{6}\right]^{+}$: 811.2003; found: 811.2004; elemental analysis calcd for $\mathrm{C}_{38} \mathrm{H}_{30} \mathrm{~F}_{6} \operatorname{IrN}_{6} \mathrm{O}_{3} \mathrm{P}$ : C 47.75, H 3.16, N 8.79; found: C 47.86, H 3.36, N 9.11.

[Ir(btp) $\left.\mathbf{2}_{2} \mathbf{( 7 )}\right] \mathbf{P F}_{6}:\left[\left\{\operatorname{Ir}(\mathrm{btp})_{2}(\mu \mathrm{Cl})\right\}_{2}\right](0.050 \mathrm{~g}, 0.038 \mathrm{mmol})$ was suspended in dry acetonitrile $(25 \mathrm{~mL})$. To this was added a solution of compound 7 $(0.026 \mathrm{~g}, 0.098 \mathrm{mmol})$ in $10 \mathrm{~mL}$ dry THF, followed by $\mathrm{NH}_{4} \mathrm{PF}_{6}(0.014 \mathrm{~g}$, $0.086 \mathrm{mmol}$ ). After being purged with argon, the reaction mixture was sealed and heated to $45^{\circ} \mathrm{C}$. The reaction was complete after $12 \mathrm{~h}$ as indi cated by TLC. The solvent was removed under reduced pressure to render a brick red residue. The crude reaction mixture was washed with THF, water and ice cold methanol, followed by diethyl ether and pen tane. The remaining product was dried under vacuum to give analytically pure compound. Yield: $0.061 \mathrm{~g} \quad(78 \%) ;{ }^{1} \mathrm{H} N M R \quad(400 \mathrm{MHz}$, $\left[\mathrm{D}_{6}\right]$ acetone): $\delta=9.48(\mathrm{~d}, 1 \mathrm{H}, J=9.0 \mathrm{~Hz}), 8.47(\mathrm{~d}, 1 \mathrm{H}, J=5.6 \mathrm{~Hz}), 8.27$ $(\mathrm{d}, 1 \mathrm{H}, J=6.3 \mathrm{~Hz}), 8.077 .98(\mathrm{~m}, 2 \mathrm{H}), 7.947 .80(\mathrm{~m}, 3 \mathrm{H}), 7.657 .30(\mathrm{~m}$, $5 \mathrm{H}), 7.20(\mathrm{dd}, 2 \mathrm{H}, J=8.9,6.3 \mathrm{~Hz}), 7.10(\mathrm{t}, 2 \mathrm{H}, J=6.4 \mathrm{~Hz}), 6.89(\mathrm{dd}, 2 \mathrm{H}$, $J=7.6,6.1 \mathrm{~Hz}), 6.456 .40(\mathrm{~m}, 1 \mathrm{H}), 6.196 .09(\mathrm{~m}, 2 \mathrm{H}), 4.704 .39(\mathrm{~m}, 1 \mathrm{H})$, $4.213 .92(\mathrm{~m}, 1 \mathrm{H}), 3.763 .52(\mathrm{~m}, 2 \mathrm{H}), 2.742 .52 \mathrm{ppm}(\mathrm{m}, 2 \mathrm{H})$; UV/Vis (acetonitrile): $\lambda_{\max }(\varepsilon)=283(31000), 325(20000), 435 \mathrm{~nm}\left(7500 \mathrm{M}^{1} \mathrm{~cm}^{1}\right)$; emission (acetonitrile): $\lambda_{\mathrm{ex}}$ (Int.) $=593$ (180), $637 \mathrm{~nm}$ (126); HRMS: calcd for $\mathrm{C}_{38} \mathrm{H}_{30} \mathrm{IrN}_{6} \mathrm{O}_{3} \mathrm{~S}_{2}\left[\begin{array}{ll}M & \mathrm{PF}_{6}\end{array}\right]^{+}$: 875.1445; found: 875.1437; elemental anal ysis calcd for $\mathrm{C}_{38} \mathrm{H}_{30} \mathrm{~F}_{6} \mathrm{IrN}_{6} \mathrm{O}_{3} \mathrm{PS}_{2}$ : C 44.75, H 2.96, N 8.24; found: C 44.88, H 3.19, N 8.27.

$\left[\operatorname{Ir}(\mathbf{p q})_{2} \mathbf{( 7 )}\right) \mathbf{P F}_{\mathbf{6}}:\left[\left\{\operatorname{Ir}(\mathrm{pq})_{2}(\mu \mathrm{Cl})\right\}_{2}\right](0.040 \mathrm{~g}, 0.031 \mathrm{mmol})$ was suspended in dry acetonitrile $(20 \mathrm{~mL})$. To this was added a solution of 7 in $10 \mathrm{~mL}$ dry THF, followed by $\mathrm{NH}_{4} \mathrm{PF}_{6}(0.013 \mathrm{~g}, 0.078 \mathrm{mmol})$. After being purged with argon, the reaction mixture was heated to $45^{\circ} \mathrm{C}$ and left to stir for $16 \mathrm{~h}$. The reaction was complete after this time period as indicated by TLC. The solvent was removed under reduced pressure to render a dark orange residue. The crude reaction mixture was washed with THF, water and ice cold acetone followed by diethyl ether and pentane. The product was vacuum dried to give analytically pure compound. Yield: $0.048 \mathrm{~g}$ $(76 \%) ;{ }^{1} \mathrm{H}$ NMR $\left(400 \mathrm{MHz}, \mathrm{CD}_{2} \mathrm{Cl}_{2}\right): \delta=8.90(\mathrm{~m}, 1 \mathrm{H}), 8.288 .13(\mathrm{~m}$, 
4H), $8.088 .05(\mathrm{~m}, 2 \mathrm{H}), 7.95(\mathrm{q}, 1 \mathrm{H}, J=5.8 \mathrm{~Hz}), 7.777 .69(\mathrm{~m}, 4 \mathrm{H}), 7.60$ $(\mathrm{q}, 1 \mathrm{H}, J=9.1 \mathrm{~Hz}), 7.397 .11(\mathrm{~m}, 7 \mathrm{H}), 6.93(\mathrm{q}, 1 \mathrm{H}, J=8.2 \mathrm{~Hz}), 6.86(\mathrm{q}$, $1 \mathrm{H}, J=7.4 \mathrm{~Hz}), 6.796 .75(\mathrm{~m}, 1 \mathrm{H}), 6.69(\mathrm{~d}, 1 \mathrm{H}, J=7.6 \mathrm{~Hz}), 6.52(\mathrm{dd}, 1 \mathrm{H}$, $J=8.5,6.7 \mathrm{~Hz}), 6.306 .26(\mathrm{~m}, 1 \mathrm{H}), 4.604 .27(\mathrm{~m}, 1 \mathrm{H}), 3.963 .95(\mathrm{~m}, 1 \mathrm{H})$, $3.713 .63(\mathrm{~m}, 2 \mathrm{H}), 2.572 .22 \mathrm{ppm}(\mathrm{m}, 2 \mathrm{H}) ;{ }^{13} \mathrm{C} \mathrm{NMR} \quad(150 \mathrm{MHz}$, $\left.\mathrm{CD}_{2} \mathrm{Cl}_{2}\right) ; \delta=171.10,170.21,151.59,149.67,148.51,148.31,148.08,147.21$, $146.88,146.41,140.43,140.19,139.85,135.77,134.94,131.99,131.76$, $131.09,130.59,129.67,129.32,128.30,128.03,127.51,127.37,127.08$, $126.97,126.64,126.03,125.79,125.25,123.68,123.57,123.26,123.05$, 117.88, 117.80, 91.31, 89.11, 69.81, 61.48, $41.99 \mathrm{ppm}$; UV/Vis (acetoni trile): $\lambda_{\max }(\varepsilon)=234(8200), 264(7600), 332 \mathrm{~nm}\left(4000 \mathrm{M}^{1} \mathrm{~cm}^{1}\right)$; emission (acetonitrile): $\lambda_{\text {ex }}$ (Int.) $=567 \mathrm{~nm}(245)$; HRMS: calcd for $\mathrm{C}_{42} \mathrm{H}_{34} \mathrm{IrN}_{6} \mathrm{O}_{3}$ [M $\left.\mathrm{PF}_{6}\right]^{+}$: 863.2322; found: 863.2328; elemental analysis calcd for $\mathrm{C}_{42} \mathrm{H}_{34} \mathrm{~F}_{6} \mathrm{IrN}_{6} \mathrm{O}_{3} \mathrm{P}: \mathrm{C} 50.05, \mathrm{H} 3.40, \mathrm{~N}$ 8.34; found: C 50.15, H 3.77, N 8.60. Luminescence measurements: Steady state luminescence spectra were re corded at room temperature on a Cary Eclipse fluorescence spectropho tometer or on an automated Photon Technology International (PTI) QM 4 fluorimeter equipped with a $150 \mathrm{~W}$ Xe arc lamp and a Hamamatsu R928 photomultiplier tube. Excitation light was excluded with suitable glass filters. Sample solutions were added to a quartz ESR tube equipped with a Teflon valve, freeze pump thaw degassed (four cycles, $1 \times$ $10{ }^{5}$ Torr), and sealed. Low temperature emission spectra were recorded in rigid solvent glass at $77 \mathrm{~K}$ by immersion of the sealed ESR tubes into a liquid nitrogen filled dewar. Time resolved phosphorescence lifetime data were recorded on a nanosecond laser system described previously. ${ }^{[75]}$

Emission quantum yields $\left(23 \pm 2^{\circ} \mathrm{C}\right)$ were measured ${ }^{[76]}$ in deoxygenated 2 methyltetrahydrofuran by referencing sample luminescence intensities to those of optically dilute standards of 9,10 diphenylanthracene $\left(\phi_{\mathrm{em}}=\right.$ 0.9 ) in cyclohexane. ${ }^{[77]}$ Quantum yields, $\phi$, were computed by using Equa tion (1):

$\phi_{\mathrm{s}}=\phi_{\mathrm{r}}\left(\frac{A_{\mathrm{r}} \eta_{\mathrm{s}}^{2} D_{\mathrm{s}}}{A_{\mathrm{s}} \eta_{\mathrm{r}}^{2} D_{\mathrm{r}}}\right)$

where $\mathrm{r}$ and $\mathrm{s}$ indicate reference and sample, respectively, $A$ is the ab sorbance at wavelength $\lambda_{\mathrm{exc}}, \eta$ is the refractive index of the solvent, and $D$ is the integrated area beneath the absorption spectrum.

Cell culture procedures: KB3 1 cells were cultured at $37^{\circ} \mathrm{C}$ in humidified air with $5 \% \mathrm{CO}_{2}$ and maintained in Dulbecco's modified Eagle's medium (Mediatech, VA) supplemented with $10 \%$ fetal bovine serum (USA Scientific), $100 \mathrm{UmL}^{1}$ penicillin (Invitrogen, NY), $100 \mu \mathrm{g} \mathrm{mL}^{1}$ streptomycin and $250 \mu \mathrm{L}$ gentamicin. The doubling time for these cells is approximately $24 \mathrm{~h}$. In cell based experiments, a fixed amount of com pound $\mathbf{8}$ was dissolved in $100 \%$ DMSO to obtain a final stock concentra tion of $100 \mathrm{~mm}$. Serial dilutions of compound 8 (10 $0.01 \mathrm{~mm})$ were then made from this stock solution using $100 \%$ DMSO as the co solvent.

Visualizing the cellular uptake of compound 8 by microscopy: The cellu lar uptake of compound $\mathbf{8}$ was visualized by microscope imaging of KB3 1 cells. Cells were plated on $35 \mathrm{~mm}$ glass bottom microwell dishes and pre incubated in the absence or presence of variable concentrations of 2 deoxyadenosine. After $24 \mathrm{~h}$, cells were treated with variable concentra tions of compound $8(0200 \mu \mathrm{M})$ for time periods varying from 4 to $48 \mathrm{~h}$. Cells were then washed twice with $1 \times$ PBS, fixed with $4 \%$ paraformalde hyde, and washed twice with $1 \times$ PBS. Images were obtained using a Nikon (TE $2000 \mathrm{~S}$ ) microscope with UV lamp. Positive controls were obtained measuring cellular uptake of Hoechst 33342 at a final concen tration of $5 \mu \mathrm{gmL}^{1}$. For the detection of compound $\mathbf{8}$, an excitation wavelength $\left(\lambda_{\mathrm{ex}}\right)$ of $365 \mathrm{~nm}$ and an emission wavelength $\left(\lambda_{\mathrm{em}}\right)$ of $477 \mathrm{~nm}$ were used.

Studies for the quantification of compound $\mathbf{8}$ were performed by seeding cells onto 12 well plates at a density of 200000 cells per well. After $24 \mathrm{~h}$, cells were treated with variable concentrations of compound 8 (0) $200 \mu \mathrm{m}$ ) for $2448 \mathrm{~h}$. Cells were treated with $0.25 \%$ trypsin and harvested by centrifugation. The supernatant was removed and then washed with PBS. Cells were lysed with $0.1 \%$ Triton X 100 in $1 \times$ PBS and then ob served using a fluorescent plate reader $\left(\lambda_{\mathrm{ex}}=340 \mathrm{~nm} / \lambda_{\mathrm{em}}=480 \mathrm{~nm}\right)$.

$\mathbf{X}$-ray single crystal structure analysis: Single crystal $\mathrm{X}$ ray data were col lected on a Bruker AXS SMART APEX CCD diffractometer using mon ochromatic $\mathrm{Mo}_{\mathrm{K} \alpha}$ radiation with the omega scan technique. The unit cells were determined using SMART ${ }^{[78]}$ and SAINT.$+{ }^{[79]}$ Data collection for all crystals was conducted at $100 \mathrm{~K}\left(173^{\circ} \mathrm{C}\right)$. All structures were solved by direct methods and refined by full matrix least squares against $F^{2}$ with all reflections using SHELXTL. ${ }^{[80]}$ Refinement of extinction coefficients was found to be insignificant. All non hydrogen atoms were refined ani sotropically. Hydrogen atoms were placed in standard calculated posi tions and were refined with an isotropic displacement parameter 1.2 times that of the adjacent carbon or oxygen.

Computations: Spin restricted density functional theory calculations were executed with Gaussian 09 (rev. A.02). ${ }^{[81]}$ Geometries were fully op timized. Calculations employed the exchange and correlation functionals of Perdew, Burke, and Ernzerhof, ${ }^{[82]}$ and the TZVP basis set. For iridium, the Stuttgart Dresden (SDD) effective core potential and basis set were used; scalar relativistic effects are included implicitly. Harmonic frequen cy calculations returned all real vibrational frequencies. The calculations, including geometry optimizations, impose continuum solvation in water, using the integral equation formalism of Tomasi's polarizable continuum model. ${ }^{[83}{ }^{86]}$ Population analyses were performed with the AOMix CDA software of Gorelsky. ${ }^{[87,88]}$

\section{Acknowledgements}

This research was supported by NSF grant CBET 1066107. We thank Professor D. G. Nocera (Harvard University) for access to instrumenta tion. T.S.T. acknowledges the Fannie and John Hertz Foundation for a graduate research fellowship. N.D. thanks the Republic of Turkey for a fellowship.

[1] Y. Yang, Q. Zhao, W. Feng, F. Li, Chem. Rev. 2013, 113, 192270.

[2] F. L. Thorp Greenwood, Organometallics 2012, 31, 56865692.

[3] M. Patra, G. Gasser, ChemBioChem 2012, 13, 12321252.

[4] E. Baggaley, J. A. Weinstein, J. A. G. Williams, Coord. Chem. Rev. 2012, 256, 17621785

[5] F. L. Thorp Greenwood, R. G. Balasingham, M. P. Coogan, J. Orga nomet. Chem. 2012, 714, 1221.

[6] K. K. W. Lo, A. W. T. Choi, W. H. T. Law, Dalton Trans. 2012, 41, 60216047.

[7] K. K. W. Lo, S. P. Y. Li, K. Y. Zhang, New J. Chem. 2011, 35, 265 287.

[8] Q. Zhao, C. Huang, F. Li, Chem. Soc. Rev. 2011, 40, 25082524.

[9] K. K. W. Lo, K. Y. Zhang, S. P. Y. Li, Pure Appl. Chem. 2011, 83, 823840.

[10] K. L. Haas, K. J. Franz, Chem. Rev. 2009, 109, 49214960.

[11] A. Ruggi, D. N. Reinhoudt, A. H. Velders, in Bioinorganic Medicinal Chemistry (Ed.: E. Alessio), Wiley, New York 2011, pp. 383406.

[12] S. Sprouse, K. A. King, P. J. Spellane, R. J. Watts, J. Am. Chem. Soc. 1984, 106, 66476653

[13] K. A. King, P. J. Spellane, R. J. Watts, J. Am. Chem. Soc. 1985, 107, 14311432.

[14] Y. Ohsawa, S. Sprouse, K. A. King, M. K. DeArmond, K. W. Hanck, R. J. Watts, J. Phys. Chem. 1987, 91, 10471054.

[15] K. Ichimura, T. Kobayashi, K. A. King, R. J. Watts, J. Phys. Chem 1987, 91, 61046106.

[16] F. O. Garces, K. A. King, R. J. Watts, Inorg. Chem. 1988, 27, 3464 3471.

[17] F. O. Garces, R. J. Watts, Inorg. Chem. 1990, 29, 582584.

[18] K. Dedeian, P. I. Djurovich, F. O. Garces, G. Carlson, R. J. Watts, Inorg. Chem. 1991, 30, 16851687.

[19] A. P. Wilde, K. A. King, R. J. Watts, J. Phys. Chem. 1991, 95, 629 634.

[20] C. Ulbricht, B. Beyer, C. Friebe, A. Winter, U. S. Schubert, $A d v$. Mater. 2009, 21, 44184441.

[21] H. Yersin, W. J. Finkenzeller, in Highly Efficient OLEDs with Phos phorescent Materials (Ed.: H. Yersin), Wiley VCH, Weinheim 2008 , pp. 197. 
[22] F. Neve, A. Crispini, S. Campagna, S. Serroni, Inorg. Chem. 1999, $38,22502258$.

[23] A. B. Tamayo, S. Garon, T. Sajoto, P. I. Djurovich, I. M. Tsyba, R. Bau, M. E. Thompson, Inorg. Chem. 2005, 44, 87238732

[24] S. Stagni, S. Colella, A. Palazzi, G. Valenti, S. Zacchini, F. Paolucci, M. Marcaccio, R. Q. Albuquerque, L. De Cola, Inorg. Chem. 2008, 47, 1050910521.

[25] A. F. Rausch, M. E. Thompson, H. Yersin, J. Phys. Chem. A 2009, $113,59275932$.

[26] N. M. Shavaleev, F. Monti, R. D. Costa, R. Scopelliti, H. J. Bolink, E. Ortí, G. Accorsi, N. Armaroli, E. Baranoff, M. Grätzel, M. K. Na zeeruddin, Inorg. Chem. 2012, 51, 22632271.

[27] N. M. Shavaleev, F. Monti, R. Scopelliti, A. Baschieri, L. Sambri, N. Armaroli, M. Grätzel, M. K. Nazeeruddin, Organometallics 2013, 32, 460467.

[28] C. Li, M. Yu, Y. Sun, Y. Wu, C. Huang, F. Li, J. Am. Chem. Soc. 2011, 133, 1123111239.

[29] D. L. Ma, W. L. Wong, W. H. Chung, F. Y. Chan, P. K. So, T. S. Lai, Z. Y. Zhou, Y. C. Leung, K. Y. Wong, Angew. Chem. 2008, 120, 3795 3799; Angew. Chem. Int. Ed. 2008, 47, 37353739.

[30] X. Wang, J. Jia, Z. Huang, M. Zhou, H. Fei, Chem. Eur. J. 2011, 17, 80288032

[31] Y. You, Y. Han, Y. M. Lee, S. Y. Park, W. Nam, S. J. Lippard, J. Am. Chem. Soc. 2011, 133, 1148811491.

[32] Y. You, S. Lee, T. Kim, K. Ohkubo, W. S. Chae, S. Fukuzumi, G. J. Jhon, W. Nam, S. J. Lippard, J. Am. Chem. Soc. 2011, 133, 18328 18342.

[33] P. K. Lee, W. H. T. Law, H. W. Liu, K. K. W. Lo, Inorg. Chem. 2011, 50,85708579

[34] P. Steunenberg, A. Ruggi, N. S. van den Berg, T. Buckle, J. Kuil, F. W. B. van Leeuwen, A. H. Velders, Inorg. Chem. 2012, 51, 2105 2114.

[35] Q. Zhao, M. Yu, L. Shi, S. Liu, C. Li, M. Shi, Z. Zhou, C. Huang, F. Li, Organometallics 2010, 29, 10851091.

[36] K. K. W. Lo, J. S. W. Chan, L. H. Lui, C. K. Chung, Organometallics 2004, 23, 31083116.

[37] K. K W. Lo, J. S. Y. Lau, Inorg. Chem. 2007, 46, 700709.

[38] K. K W. Lo, K. Y. Zhang, S. K. Leung, M. C. Tang, Angew. Chem. 2008, 120, 2245 2248; Angew. Chem. Int. Ed. 2008, 47, 22132216.

[39] K. K. W. Lo, K. Y. Zhang, C. K. Chung, K. Y. Kwok, Chem. Eur. J. 2007, 13, 71107120.

[40] H. W. Liu, K. Y. Zhang, W. H. T. Law, K. K. W. Lo, Organometallics 2010, 29, 34743476.

[41] J. S. Choi, A. J. Berdis, Future Med. Chem. 2012, 4, 14611478.

[42] K. M. Smith, M. D. Slugoski, S. K. Loewen, A. M. Ng, S. Y. Yao, X. Z. Chen, E. Karpinski, C. E. Cass, S. A. Baldwin, J. D. Young, J. Biol. Chem. 2005, 280, 2543625449.

[43] A. J. Berdis, Biochemistry 2008, 47, 82538260.

[44] W. Plunkett, V. Gandhi, Hematol. Cell Ther. 1996, 38 Suppl 2, S67 74.

[45] V. Gandhi, W. Plunkett, Clin. Pharmacokinet. 2002, 41, 93103.

[46] W. B. Parker, J. A. Secrist 3rd, W. R. Waud, Curr. Opin. Investig. Drugs 2004, 5, 592596.

[47] V. Gandhi, W. Plunkett, Curr. Opin. Oncol. 2006, 18, 584590.

[48] D. S. Gesto, N. M. F. S. A. Cerqueira, P. A. Fernandes, M. J. Ramos, Curr. Med. Chem. 2012, 19, 10761087.

[49] P. W. Marks, Expert Rev. Anticancer Ther. 2012, 12, 299305.

[50] C. A. Koczor, R. A. Torres, W. Lewis, Expert Opin. Drug Metab. Toxicol. 2012, 8, 665676.

[51] T. Robak, P. Robak, Curr. Pharm. Des. 2012, 18, 33733388.

[52] Z. L. Johnson, C. G. Cheong, S. Y. Lee, Nature 2012, 483, 489493.

[53] For an alternative metalation, see: A. Maity, B. L. Anderson, N. De ligonul, T. G. Gray, Chem. Sci. 2013, 4, 11751181.

[54] For examples of cyclometalated iridium(III) complexes bearing one chelating triazole or triazolate ligand, see: a) S. Liu, P. Müller, M. K. Takase, T. M. Swager, Inorg. Chem. 2011, 50, 7598 7609; b) S. Za narini, M. Felici, G. Valenti, M. Marcaccio, L. Prodi, S. Bonacchi, P. Contreras Carballada, R. M. Williams, M. C. Feiters, R. J. M. Nolte, L. De Cola, F. Paolucci, Chem. Eur. J. 2011, 17, 4640 4647; c) B.
Beyer, C. Ulbricht, D. Escudero, C. Friebe, A. Winter, L. González, U. S. Schubert, Organometallics 2009, 28, 5478 5488; d) E. Orselli, R. Q. Albuquerque, P. M. Fransen, R. Fröhlich, H. M. Janssen, L. De Cola, J. Mater. Chem. 2008, 18, 45794590.

[55] J. M. Fernández Hernández, J. I. Beltrán, V. Lemaur, M. D. Gálvez López, C. H. Chien, F. Polo, E. Orselli, R. Fröhlich, J. Cornil, L. De Cola, Inorg. Chem. 2013, 52, 18121824.

[56] K. N. Swanick, S. Ladouceur, E. Zysman Colman, Z. Ding, Chem. Commun. 2012, 48, 31793181.

[57] A. B. Tamayo, B. D. Alleyne, P. I. Djurovich, S. Lamansky, I. Tsyba, N. N. Ho, R. Bau, M. E. Thompson, J. Am. Chem. Soc. 2003, 125, 73777387.

[58] Y. You, W. Nam, Chem. Soc. Rev. 2012, 41, 70617084.

[59] R. S. Mulliken, J. Chem. Phys. 1955, 23, 18331840.

[60] L. Dagnino, L. L. Bennett, Jr., A. R. P. Paterson, J. Biol. Chem. 1991, 266, 63126317.

[61] M. M. Gutierrez, K. M. Giacomini, Biochim. Biophys. Acta 1993, 1149, 202208.

[62] M. E. Schaner, J. Wang, L. Zhang, S. F. Su, K. M. Gerstin, K. M Giacomini, J. Pharmacol. Exp. Ther. 1999, 289, 14871491.

[63] K. M. King, V. L. Damaraju, M. F. Vickers, S. Y. Yao, T. Lang, T. E. Tackaberry, D. A. Mowles, A. M. Ng, J. D. Young, C. E. Cass, Mol. Pharmacol. 2006, 69, 346353.

[64] A. N. Elwi, V. L. Damaraju, M. L. Kuzma, D. A. Mowles, S. A. Bald win, J. D. Young, M. B. Sawyer, C. E. Cass, Am. J. Physiol. Renal Physiol. 2009, 296, F1439 1451

[65] H. Li, G. A. Smolen, L. F. Beers, L. Xia, W. Gerald, J. Wang, D. A. Haber, S. B. Lee, PLoS One 2008, 3, e2353.

[66] D. A. Griffith, S. M. Jarvis, Biochim. Biophys. Acta 1996, 1286, 153 181.

[67] M. Podgorska, K. Kocbuch, T. Pawelczyk, Acta Biochim. Pol. 2005 , $52,749758$.

[68] V. Rolland, M. Kotera, J. Lhomme, Synth. Commun. 1997, 27, 3505 3511.

[69] M. Nonoyama, Bull. Chem. Soc. Jpn. 1974, 47, 767768.

[70] E. Baranoff, B. F. E. Curchod, J. Frey, R. Scopelliti, F. Kessler, I. Tavernelli, U. Rothlisberger, M. Graetzel, Md. K. Nazeeruddin, Inorg. Chem. 2012, 51, 215224.

[71] I. Shin, S. Yoon, J. I. Kim, J. Lee, T. H. Kim, H. Kim, Electrochim. Acta 2011, 56, 62196223.

[72] T. Peng, Y. Yang, Y. Liu, D. Ma, Z. Houc, Y. Wang, Chem. Commun. 2011, 47, 31503152.

[73] M. Schmittel, S. Qinghai, Chem. Commun. 2012, 48, 27072709.

[74] S. Lamansky, P. Djurovich, D. Murphy, F. Abdel Razzaq, H. Lee, C. Adachi, P. E. Burrows, S. R. Forrest, M. E. Thompson, J. Am. Chem. Soc. 2001, 123, 43044312.

[75] E. J. McLaurin, A. B. Greytak, M. G. Bawendi, D. G. Nocera, J. Am Chem. Soc. 2009, 131, 1299413001.

[76] J. N. Demas, G. A. Crosby, J. Phys. Chem. 1971, 75, 9911024.

[77] S. Hamai, F. Hirayama, J. Phys. Chem. 1983, 87, 8389.

[78] Bruker Advanced X ray Solutions, SMART for WNT/2000 (Version 5.628), Bruker AXS, Inc., Madison, WI, 19972002.

[79] Bruker Advanced X ray Solutions, SAINT, Version 6.45, Bruker AXS, Inc., Madison, WI, 19972003.

[80] Bruker Advanced X ray Solutions, SHELXTL, Version 6.10, Bruker AXS, Inc., Madison, WI, 2000.

[81] Gaussian 09 (Revision A.02), M. J. Frisch, G. W. Trucks, H. B. Schle gel, G. E. Scuseria, M. A. Robb, J. R. Cheeseman, G. Scalmani, V. Barone, B. Mennucci, G. A. Petersson, H. Nakatsuji, M. Caricato, X Li, H. P. Hratchian, A. F. Izmaylov, J. Bloino, G. Zheng, J. L. Son nenberg, M. Hada, M. Ehara, K. Toyota, R. Fukuda, J. Hasegawa, M. Ishida, T. Nakajima, Y. Honda, O. Kitao, H. Nakai, T. Vreven, J. A. Montgomery, Jr., J. E. Peralta, F. Ogliaro, M. Bearpark, J. J. Heyd, E. Brothers, K. N. Kudin, V. N. Staroverov, R. Kobayashi, J. Normand, K. Raghavachari, A. Rendell, J. C. Burant, S. S. Iyengar J. Tomasi, M. Cossi, N. Rega, J. M. Millam, M. Klene, J. E. Knox, J. B. Cross, V. Bakken, C. Adamo, J. Jaramillo, R. Gomperts, R. E Stratmann, O. Yazyev, A. J. Austin, R. Cammi, C. Pomelli, J. W. Ochterski, R. L. Martin, K. Morokuma, V. G. Zakrzewski, G. A. 
Voth, P. Salvador, J. J. Dannenberg, S. Dapprich, A. D. Daniels, Ö. Farkas, J. B. Foresman, J. V. Ortiz, J. Cioslowski, and D. J. Fox, Gaussian, Inc., Wallingford CT, 2009.

[82] J. P. Perdew, K. Burke, M. Ernzerhof, Phys. Rev. Lett. 1996, 77, 38653868.

[83] S. Miertus, E. Scrocco, J. Tomasi, Chem. Phys. 1981, 55, 117129.

[84] J. Tomasi, B. Mennucci, R. Cammi, Chem. Rev. 2005, 105, 2999 3093.

[85] E. Cancès, B. Mennucci, J. Tomasi, J. Chem. Phys. 1997, 107, 3032 3041
[86] B. Mennucci, E. Cancès, J. Tomasi, J. Phys. Chem. B 1997, 101, 1050610517.

[87] S. I. Gorelsky, AOMix: Program for Molecular Orbital Analysis, York University, Toronto, 1997: http://www.sg chem.net.

[88] S. I. Gorelsky, A. B. P. Lever, J. Organomet. Chem. 2001, 635, 187 196.

Post-print standardized by MSL Academic Endeavors, the imprint of the Michael Schwartz Library at Cleveland State University, 2017. 